Journal of

Molecular Microbiology

and Biotechnology
J Mol Microbiol Biotechnol 2008;15:255-263

DOI: $10.1159 / 000108656$

Published online: September 20, 2007

\title{
Differential Regulation of Ota and Otb, Two Primary Glycine Betaine Transporters in the Methanogenic Archaeon Methanosarcina mazei Gö1
}

\author{
R. Spanheimer ${ }^{a} \quad$ M. Hoffmann ${ }^{b} \quad$ S. Kögl ${ }^{b} \quad$ S. Schmidt ${ }^{a} \quad$ K. Pflüger ${ }^{b} \quad$ V. Müller ${ }^{a}$ b \\ ${ }^{a}$ Molecular Microbiology and Bioenergetics, Institute of Molecular Biosciences, Johann Wolfgang Goethe \\ University Frankfurt, Frankfurt am Main, and ${ }^{b}$ Division of Microbiology, Ludwig Maximilian University München, \\ München, Germany
}

Key Words

Archaea - Osmoadaptation · Methanogen • Betaine transport regulation

\begin{abstract}
Methanogenic archaea accumulate glycine betaine in response to hypersalinity, but the regulation of proteins involved, their mechanism of activation and regulation of the corresponding genes are largely unknown. Methanosarcina mazei differs from most other methanoarchaea in having two gene clusters both encoding a potential glycine betaine transporter, Ota and Otb. Western blot as well as quantitative real-time PCR revealed that Otb is not regulated by osmolarity. On the other hand, cellular levels of Ota increased with increasing salt concentrations. A maximum was reached at $300-500 \mathrm{~mm} \mathrm{NaCl}$. Ota concentrations reached a maximum $4 \mathrm{~h}$ after an osmotic upshock. Hyperosmolarity also caused an increase in cellular Ota concentrations. In addition to osmolarity Ota expression was regulated by the growth phase. Expression of Ota as well as transport of betaine was downregulated in the presence of glycine betaine.
\end{abstract}

Copyright $\odot 2007$ S. Karger AG, Basel

\section{KARGER}

Fax +41613061234 E-Mail karger@karger.ch www.karger.com
(C) 2007 S. Karger AG, Basel

$1464-1801 / 08 / 0154-0255 \$ 24.50 / 0$

Accessible online at:

www.karger.com $/ \mathrm{mmb}$

\section{Introduction}

Methanogenic archaea are a nutritionally rather uniform group of organisms that grow by the conversion of a small number of $\mathrm{C} 1$ compounds or acetate to methane [Deppenmeier, 2002b; Ferry, 1992; Thauer, 1998]. Most methanogens can grow on $\mathrm{H}_{2}+\mathrm{CO}_{2}$, but only the Methanosarcinaea can also grow by the conversion of methyl group containing compounds such as methanol and methylamines or acetate [Deppenmeier, 2002a]. Methanogens comprise the last limb of the anaerobic food chain in anoxic terrestrial ecosystems, and they are ubiquitous in nature. For example, they have been isolated from the Antarctica as well as extremely hot environments and they are present in freshwater, marine or even saline habitats [Jones et al., 1987].

The presence of methanogens in ecosystems with very different salinities indicates that they have mechanisms to cope with salt or osmostress. Generally, hypersalinity causes water flux from the cytoplasm and will lead to cell death if no counter measures are taken [Csonka, 1989; Kempf and Bremer, 1998; Wood, 1999; Wood et al., 2001]. Like other living cells, methanogens cope with salt stress by the accumulation of compatible solutes, a class of
V. Müller

Molecular Microbiology and Bioenergetics, Institute of Molecular Bioscience Johann Wolfgang Goethe University Frankfurt, Max-von-Laue-Strasse 9 DE-60438 Frankfurt (Germany)

Tel. +49 6979829 507, Fax +49 6979829 306, E-Mail vmueller@bio.uni-frankfurt.de 
small, highly soluble compounds that do not interfere with the metabolism and whose intracellular concentrations can be varied over a wide range [Brown, 1976]. The compounds accumulated include glycine betaine, $\beta$-glutamine, $\mathrm{N} \varepsilon$-acetyl- $\beta$-lysine, di-myo-1,1'-inositol phosphate (DIP), cyclic-2,3-diphospho-glycerate (cDPG), 1,3,4,6-hexanetetracarboxylic acid (HTC), $\alpha$-glucosylglycerate, $\alpha$-glutamate, and $\beta$-glutamate [Lai et al., 1991; Martins et al., 1997; Roessler and Müller, 2001; Roberts, 2004; Robertson et al., 1992a, b; Müller et al., 2005; Sowers and Gunsalus, 1995; Sowers et al., 1990]. Accumulation is either by de novo synthesis or uptake from the environment but as in other cells, uptake is preferred for energetic reasons over de novo synthesis. However, the molecular basis of osmoregulation in methanogenic archaea is unknown.

Glycine betaine is a common compatible solute accumulated by every methanogen investigated so far. Only halophilic methanogens such as Methanohalophilus species can synthesize glycine betaine de novo, all others will take it up from the environment [Lai and Gunsalus, 1992; Roberts et al., 1992; Robertson et al., 1990]. Transport and inhibitor studies using whole cells suggested the presence of secondary ion-coupled glycine betaine transporters in Methanosarcina thermophila and Methanohalophilus portucalensis [Lai et al., 2000; Proctor et al., 1997] and a primary, ATP-driven transporter in Methanosarcina mazei Gö1 [Roessler et al., 2002]. Despite their importance for osmoprotection, regulation of solute transporter in archaea is only poorly understood. The genome of Methanosarcina mazei Gö1 encodes two primary, ATP-driven transporters with high similarity to glycine betaine transporters from bacteria, Ota and Otb. They are composed of three subunits, a cytoplasmic ATP hydrolyzing subunit (otaA and $o t b A$ ), a transmembrane transporter subunit (otaB and $o t b B 1 / o t b B 2)$ and a substrate binding protein (otaC and $o t b C$ ). Ota was shown biochemically to indeed catalyze glycine betaine transport [Schmidt, Spanheimer, Müller, unpubl.]. Northern blot analysis demonstrated that cellular mRNA levels of OtaC, encoding the binding protein of the $\mathrm{ABC}$-transporter, were increased at $400 \mathrm{mM} \mathrm{NaCl}$ in steady state of growth [Roessler et al., 2002]. However, a quantitative and more defined analysis was not performed. Furthermore, at that time, the presence of Otb was unknown. We have followed up these studies and will present here a detailed analyses of the regulation of Ota and Otb of M. mazei on the level of gene expression, cellular protein levels and transport activity.

\section{Results}

Nucleotide Sequence and Structure of the otb Gene Cluster from M. mazei Gö1

Inspection of genomic sequences of methanogenic archaea revealed the presence of potential primary transporters for glycine betaine in Methanosarcina mazei, Methanosarcina acetivorans, Methanohalophilus portucalensis, Methanococcoides burtonii, Methanosarcina barkeri, and Methanococcus maripaludis (fig. 1). Apparently, M. mazei and M. burtonii are the only organisms that encode two transporters with similarity to glycine betaine transporters. OtaC and Mbur_0503 are similar to each other (similarity $83 \%$, identity $69 \%$ ). The genetic organization of the ota operon was described recently [Roessler et al., 2002]. The otb gene cluster contains four genes arranged in the order $o t b C$, otbA, otbB1, and $o t b B 2$. $o t b C$ and $o t b A$ are separated by $25 \mathrm{bp}$ and $o t b A$ and $o t b B 1$ by $236 \mathrm{bp}$, whereas $o t b B 1$ and $o t b B 2$ overlap by $10 \mathrm{bp} .313$ bp downstream of the stop codon of otbB2 is the start codon of a putative $\mathrm{Na}^{+} / \mathrm{H}^{+}$antiporter. otbA, otbB1, otbB2, and $o t b C$ are $1124,662,620$, and $920 \mathrm{bp}$, respectively. Sequence analysis revealed putative Shine Dalgarno sequences for every gene of the otb gene cluster.

Properties of the otb Gene Products and Similarities to Other Proteins

The ATP-hydrolyzing subunit OtbA is a hydrophilic protein of $M_{r} 41,900$. Like OtaA it contains a Walker motif indicative for ATP binding. OtbB1 is of $M_{r} 23,600$ and OtbB2 is of $M_{r} 22,000$. Both are very similar to transmembrane proteins of known ABC transporters. Hydrophobicity plots predicted six transmembrane helices for each protein and, therefore, both proteins may form a heterodimer to create the membrane spanning domain of the transporter. OtbC is of $\mathrm{M}_{\mathrm{r}} 34,300$. It is similar to substrate-binding proteins of other transport systems. BLAST searches revealed ProX of Archaeoglobus fulgidus and the putative glycine betaine binding protein (Mbur 0489) from Methanococcoides burtonii as closest homologues to OtbC, indicating that $o t b C$ encodes a glycine betaine transporter. The similarity to ProX of $A$. fulgidus is $75 \%$, the identity $55 \%$. A sequence comparison and the conservation of the glycine betaine binding box [Schiefner et al., 2004b] in OtbC corroborates this assumption. Interestingly OtaC was not picked up in a BLAST search with OtbC as query.
Spanheimer/Hoffmann/Kögl/Schmidt/ Pflüger/Müller 

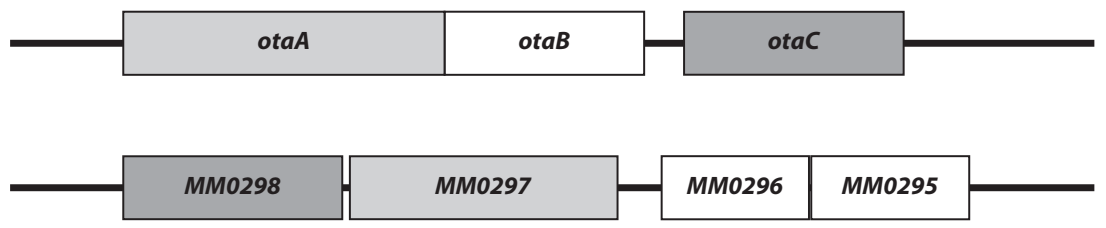

M. acetivorans C2A

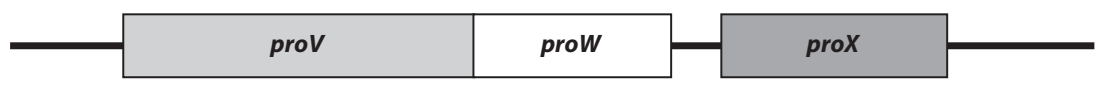

M. portucalensis

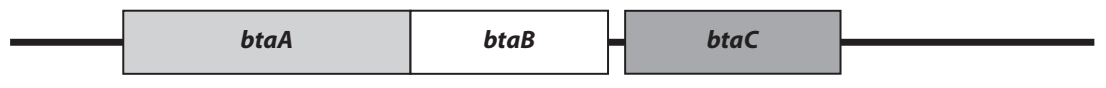

M. burtonii DSM 6242

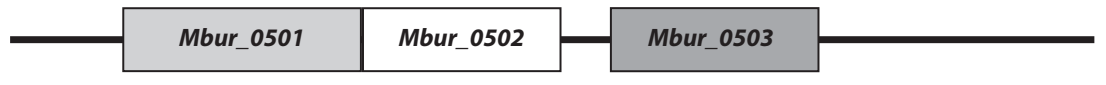

M. burtonii DSM 6242

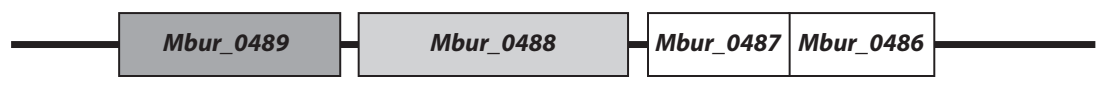

M. barkeri Fusaro

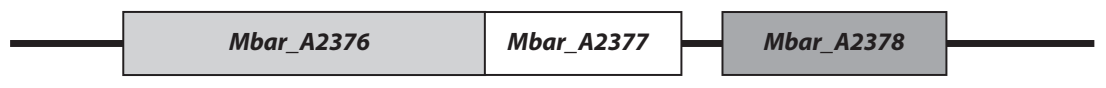

M. maripaludis S2

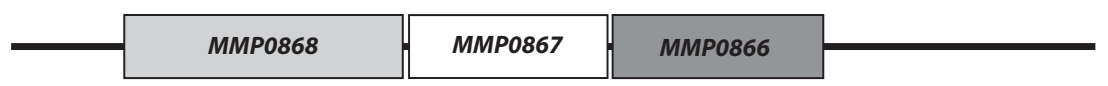

Fig. 1. Compilation of genes potentially encoding ABC-type transporters for glycine betaine in methanogenic archaea. The genes encoding the substrate binding domain, the transmembrane domain, and the ATP-binding domain are given in dark grey, white, and light grey. Sequences were identified in the 'membrane transport database' [www.membranetransport.org] and by BLAST search using Ota subunits as query. Genome accession numbers: M. mazei (AE008384); M. acetivorans C2A (AE010299); M. burtonii DSM 6242 (CP000300), M. barkeri Fusaro (CP000099); M. maripaludis S2 (BX950229). otaA, btaA, and proV are coding for the ATP-binding protein, $o t a B, b t a B$, and proW for the membrane spanning protein, and $o t a C, b t a C$ and proX for the extracellular glycine binding protein (ota: AF475089; bta: AY876914).

The Cellular Level of OtbC Is Not Affected by the

Salinity of the Medium

To determine the cellular level of OtbC cells were grown with methanol as carbon and energy source and different salinities. The intracellular concentration of OtbC was analyzed in Western blots using an antiserum derived against heterologously produced OtbC. OtbC levels were close to detection limit, indicating low expression rates compared to OtaC. However, the cellular level of OtbC did not change with the growth phase and did not increase after an osmotic upshock (from 38.5 to 400 $\mathrm{mM} \mathrm{NaCl}$, measured for a 7-hour time interval that allowed for production of OtaC, see below). Furthermore, quantitative real-time PCR revealed that transcription of $o t b A, o t b B_{1}, o t b B_{2}$, and $o t b C$ was not affected by the salinity $(38.5-800 \mathrm{mM} \mathrm{NaCl})$ of the medium (data not shown). 


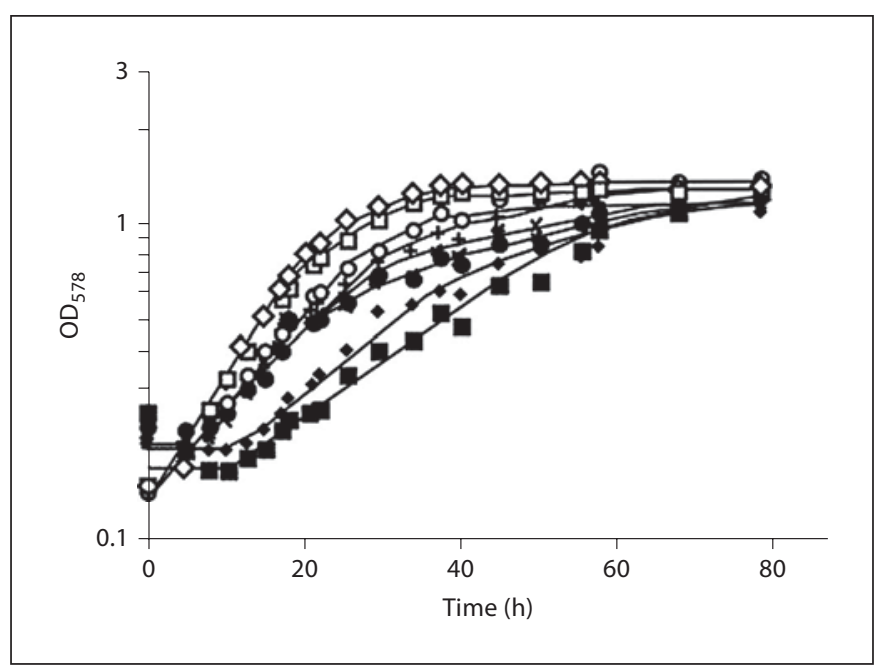

Fig. 2. Growth of M. mazei $\mathrm{Gö1}$ at different $\mathrm{NaCl}$ concentrations. Cells of M. mazei Gö1 were grown in complex medium on methanol $(150 \mathrm{mM})$ in the presence of $(\bigcirc) 38.5,(\square) 100,(\diamond) 200,(+)$ 300, (×) 400, (*) 500, (•) 600, (ם) 700, or ( $800 \mathrm{~mm} \mathrm{NaCl}$. The cultures were inoculated (10\%) from a preculture grown at 38.5 $\mathrm{mM} \mathrm{NaCl}$.

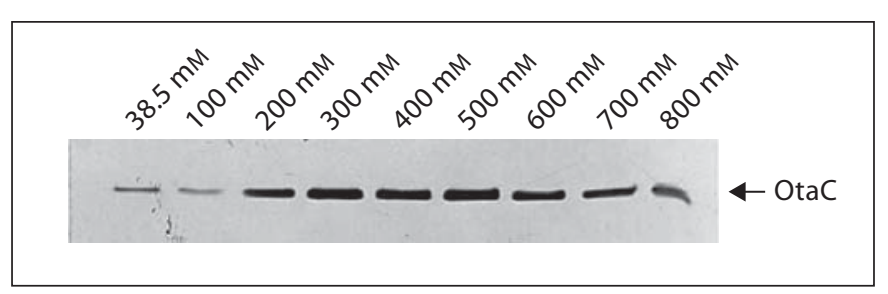

Fig. 3. The cellular OtaC content is salt dependent. Cell extracts of $M$. mazei Gö1 from cells grown at the salt concentration indicated were separated by SDS-PAGE, transferred to nitrocellulose membranes, and OtaC was detected with a specific antiserum.

The Cellular Level of OtaC Increases with Increasing Salinity

To analyze the effect of external salinity on cellular OtaC levels, cells were grown in complex media with methanol as carbon and energy source in the presence of $38.5,100,200,300,400,500,600,700$ or $800 \mathrm{mM} \mathrm{NaCl}$. An increase in the salt concentration up to $600 \mathrm{mM} \mathrm{NaCl}$ had no significant effect on lag phases or growth rates (fig. 2), only at 700 and $800 \mathrm{~mm} \mathrm{NaCl}$ there was a small lag phase of about $10 \mathrm{~h}$ and the growth rate was decreased. The higher the salt concentration, the earlier was the onset of the stationary phase. Samples were taken at the mid-exponential growth phase $\left(\mathrm{OD}_{578}=0.4-0.5\right)$ and probed in Western blots with OtaC antiserum generated against heterologously produced OtaC. As can be seen in figure 3, the cellular level of OtaC was relatively low at $38.5 \mathrm{mM} \mathrm{NaCl}$. This low level may result from basal transcription at low salt and/or transfer form stationary phase cultures (see below). However, the amount of OtaC at low salt varied from below detection limit to very low levels in different cultures, but increased with external salinity. A maximum was reached at $300-500 \mathrm{mM} \mathrm{NaCl}$ (3- to 3.5fold increase compared to $38.5 \mathrm{mM})$. Thereafter, it declined somewhat but still remained 2- to 2.5-fold higher at 700 and $800 \mathrm{~mm} \mathrm{NaCl}$. These data clearly demonstrate a NaCl-dependent increase in the cellular level of OtaC. However, it should be noted that there is a basal level of OtaC present in cells grown at low salinity.

\section{The Cellular Level of OtaC Increases with Increasing Osmolarity}

Non-halophilic bacteria do not only accumulate compatible solutes in response to elevated salinities but, more general, to elevated osmolarities [Mohrbach and Krämer, 2002; Poolman and Glaasker, 1998; Roessler and Müller, 2001; Sleator and Hill, 2001; ]. Therefore, it was of interest to determine whether the increase in OtaC level was salt specific or could also be induced by high osmolarity. To address this question, cells of $M$. mazei were grown on methanol in complex media that contained high amounts of $\mathrm{NaCl}$ or sugars. Because growth of methanogens is strictly $\mathrm{Na}^{+}$-dependent [Becher and Müller, 1994; Perski et al., 1982], the media contained at least $38.5 \mathrm{mM} \mathrm{NaCl}$. In the presence of sodium gluconate, growth of the cells was comparable to growth in the presence of $\mathrm{NaCl}$; however, cells were extremely sensitive to mechanical stress and in fact, every culture lysed after the first sample had been taken. In the presence of glucose, growth rates and final optical densities decreased. Interestingly, the increase in osmolarity caused by addition of sodium gluconate or glucose also led to an increase in OtaC levels. The induction factors in cells grown in the presence of sodium gluconate or glucose were comparable (fig. 4). These experiments clearly demonstrate that induction of OtaC is triggered by an increase in osmolarity and independent of $\mathrm{Na}^{+}$and/or $\mathrm{Cl}^{-}$.

\section{Cellular OtaC Levels Are Not Affected by Oxygen or Temperature Stress}

To determine whether cellular OtaC levels are also affected by other stresses, cells were grown with methanol in complex media in Hungate tubes containing $38.5 \mathrm{~mm}$ $\mathrm{NaCl}$. In the mid-exponential growth phase, the temperature was raised from 37 to $45^{\circ} \mathrm{C}$ or $5 \mathrm{ml}$ air was injected. 
In both cases, growth continued for about $10 \mathrm{~h}$, but declined afterwards. Neither stressor had an effect on cellular OtaC levels, even after $5 \mathrm{~h}$ of incubation (data not shown), a time sufficient to produce OtaC (see below).

\section{Kinetics of OtaC Production}

To analyze the time dependence of the increase of cellular OtaC concentrations, cells of M. mazei Gö1 were grown at $38.5 \mathrm{mM} \mathrm{NaCl}$ to mid-exponential growth phase. Then the $\mathrm{NaCl}$ concentration was suddenly increased to $400 \mathrm{~mm}$. This upshock led to a growthstop and a lag phase of $4 \mathrm{~h}$ before growth resumed (data not shown). There was only little OtaC before the upshock. The first significant increase in OtaC levels were detected $3 \mathrm{~h}$ after the shock and a maximum was obtained $4 \mathrm{~h}$ after the shock (fig. 5). This level remained unchanged up to stationary growth phase. It should be noted that in nonshocked cells OtaC levels began to increase during late exponential growth phase until a maximum was reached in early stationary phase indicating a second, growth phase-dependent regulation of the cellular OtaC content.

\section{Expression of ota Is Salt Dependent}

In previous experiments Northern blot analyses revealed elevated otaC mRNA levels in steady state cultures at $400 \mathrm{mM} \mathrm{NaCl}$ compared to $38.5 \mathrm{mM} \mathrm{NaCl}$ [Roessler et al., 2002]. However, quantification of the data proved difficult. Therefore, we used quantitative real-time PCR here and in addition analyzed expression levels not only for otaC but every gene of the operon. Therefore, cells were grown with methanol as carbon and energy source in the presence of different salinities. RNA was isolated from salt-adapted cultures, transcribed into cDNA and real time PCR was performed with gene specific primers. There was no expression at low salt and presence of glycine betaine. Expression of ota was clearly salt dependent. At $400 \mathrm{~mm} \mathrm{NaCl}$, the cellular levels of otaA, otaB, and otaC were 11-, 15-, and 18-fold, respectively, increased compared to $38.5 \mathrm{mM}$. A further increase to $800 \mathrm{mM}$ $\mathrm{NaCl}$ led to a slight increase of otaA but slight decrease of $o t a B$ and $o t a C$ levels (fig. 6).

\section{Regulation of ota by Glycine Betaine}

Next, it was analyzed whether uptake of glycine betaine will relief the osmostress signal leading to a decrease in otaC mRNA levels. When grown in minimal medium at $400 \mathrm{~mm} \mathrm{NaCl}$, cells accumulated mainly glutamate $(0.58 \mu \mathrm{mol} / \mathrm{mg}$ protein $)$, at $800 \mathrm{mM} \mathrm{NaCl}$ glutamate $(0.74$ $\mu \mathrm{mol} / \mathrm{mg}$ protein $)$ and $\mathrm{N}^{\varepsilon}$-acetyl- $\beta$-lysine $(0.91 \mu \mathrm{mol} /$

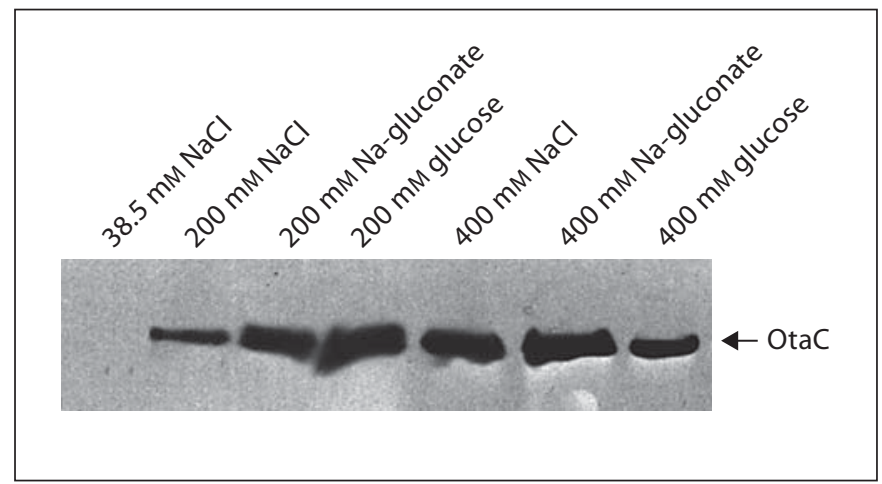

Fig. 4. OtaC is induced by increased osmolarity. Cells of M. mazei Gö1 were grown in the presence of sugars or salts as indicated in the presence of at least $38.5 \mathrm{mM} \mathrm{NaCl}$. At an $\mathrm{OD}_{578}$ of 0.4 samples were taken, cells were lysed, separated by SDS-PAGE, transferred to nitrocellulose membranes, and OtaC was detected with a specific antiserum.

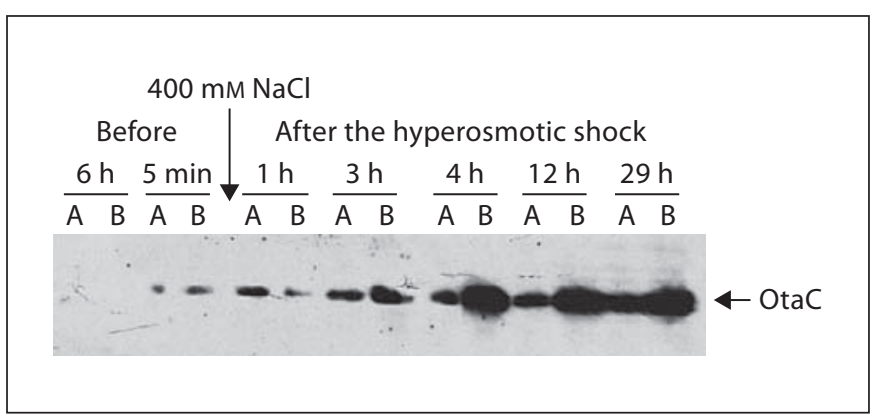

Fig. 5. Kinetics of OtaC production in M. mazei Gö1. Cultures A and $\mathrm{B}$ were grown on complex medium on methanol with 38.5 $\mathrm{mM} \mathrm{NaCl}$. At an $\mathrm{OD}_{578}$ of 0.4 the $\mathrm{NaCl}$ concentration in culture $\mathrm{B}$ was increased to $400 \mathrm{mM}$. Culture A served as control. At the time points indicated samples were taken and OtaC levels were analyzed with specific antiserum.

mg protein). When glycine betaine (1 $\mathrm{mM})$ was supplied to the medium, it was taken up by M. mazei, and the levels of glutamate and $\mathrm{N}^{\varepsilon}$-acetyl- $\beta$-lysine were reduced (fig. 7). At the same time, cellular levels of otaA, otaB, and otaC were reduced up to $52 \%$ (fig. 6) indicating a downregulation of ota expression by glycine betaine. However, it is noteworthy that expression of ota genes was reduced but not abolished by glycine betaine.

To study the effect of glycine betaine on transport activity, cells were grown at different salinities in absence or presence $(1 \mathrm{mM})$ of glycine betaine, harvested, and the transport of $\left[{ }^{14} \mathrm{C}\right]$ glycine betaine was analyzed with resting cell suspensions. Again, cells accumulated glutamate 
Fig. 6. Expression of ota is salt dependent. M. mazei cells were cultivated in minimal medium at salinities as indicated and in presence $(1 \mathrm{mM})$ or absence of glycine betaine. Total RNA was isolated and transcribed into cDNA, and relative transcription levels were measured using real-time PCR analysis. In the diagram, a relative quantitation of transcript levels is given. All values are compared to the ' $38.5 \mathrm{~mm}$ $\mathrm{NaCl}$, -betaine' value, which was defined as 1 . The experiment was repeated in 3 independent parallels to ensure statistical relevance.

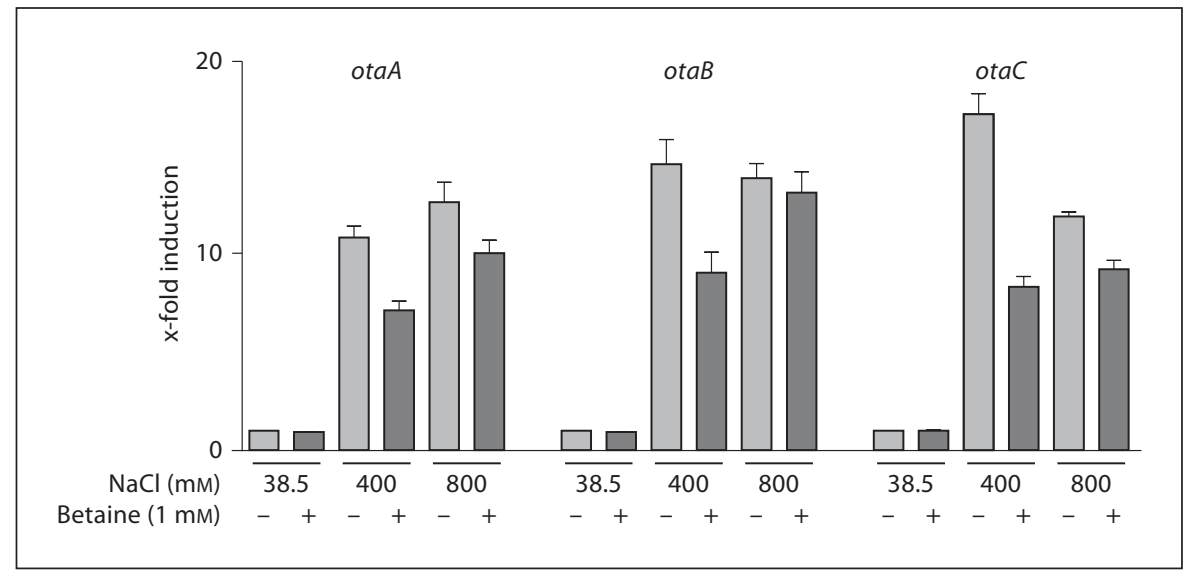

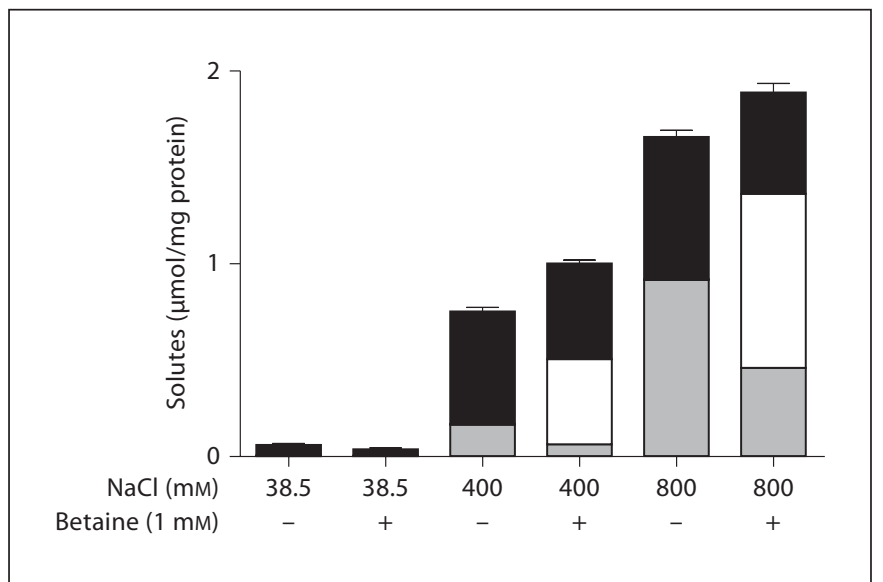

Fig. 7. Distribution of compatible solutes in M. mazei. M. mazei was cultivated in minimal medium at salinities as indicated in the presence $(1 \mathrm{mM})$ or absence of glycine betaine. The cells were harvested in the exponential phase, washed and freeze-dried. The internal concentration of the compatible solutes $\mathrm{N}^{\varepsilon}$-acetyl- $\beta$-lysine (grey bars), glycine betaine (white bars) and glutamate (black bars) was measured by NMR.

(biosynthesis) and glycine betaine (uptake) from the medium during growth. Therefore, there is no driving force for net uptake of glycine betaine during the transport experiment. It is apparent from figure 8 , that the rate of $\left[{ }^{14} \mathrm{C}\right]$ glycine betaine uptake was neglectable at low salt but increased at higher salt concentrations, as seen before [Roeßler et al., 2002]. Most interestingly, when cells were grown in the presence of glycine betaine transport activity was reduced by about $90 \%$. In contrast to gene expression, transport activity was nearly completely reduced, indicating control of glycine betaine uptake by both control of ota expression but more pronounced by regulation of the activity of the transporter. Taken together, these

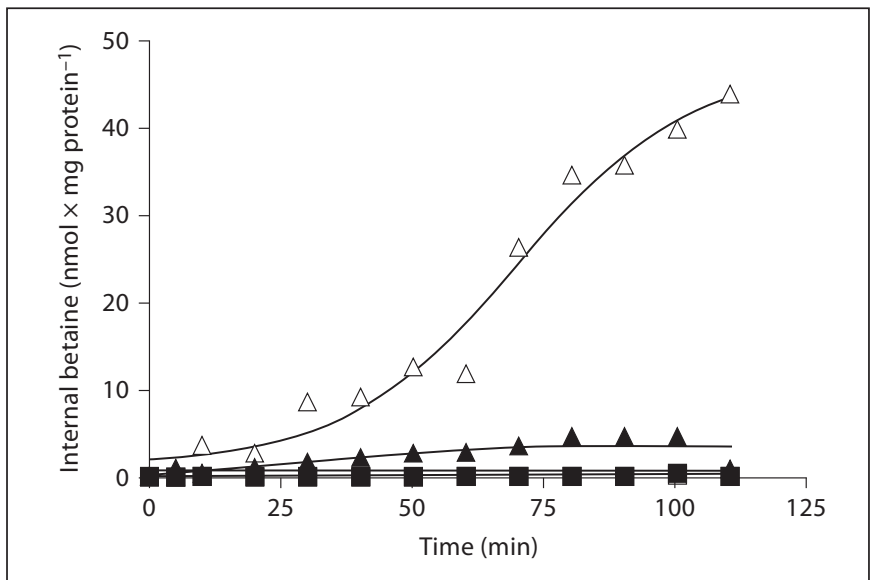

Fig. 8. Feedback inhibition of glycine betaine transport activity in cultures grown in the presence of glycine betaine. M. mazei cells were cultivated in minimal medium at different salinities ( $\square 38.5$ $\mathrm{mM}$ and $\triangle 400 \mathrm{mM} \mathrm{NaCl}$ ) in the presence (1 mM, filled symbols) or absence of glycine betaine (open symbols). Uptake of glycine betaine was determined as described in 'Experimental Procedures'.

experiments clearly demonstrate downregulation of ota gene expression and reduced transport activity in cells grown at high salt and presence of glycine betaine.

\section{Discussion}

Sequence analyses revealed the presence of two gene clusters in M. mazei that potentially encode glycine betaine transporters. This is supported by a high degree of similarity of the most conserved subunits, the substrate binding proteins to glycine betaine binding proteins from other bacteria and archaea. However, OtaC and OtbC are 
divergent enough not to be picked up by BLAST searches using either one of the two as the query. OtaC is most similar to ProX of Methanosarcina acetivorans C2A and OtbC is most similar to Mbur_0503 of Methanococcoides burtonii DSM 6242 and ProX of Archaeoglobus fulgidus. Recently, the three-dimensional structures of the glycine betaine-binding proteins ProX of E. coli [Schiefner et al., 2004a], OpuAC of B. subtilis [Horn et al., 2005] and ProX of A. fulgidus [Schiefner et al., 2004b] have been solved on an atomic level. These studies revealed a tryptophan box involved in glycine betaine binding. This box is conserved in both OtaC and OtbC. However, as noted by Horn et al. [2006] OtaC of M. mazei can only be aligned to OpuAC of B. subtilis if the N- and C-terminal halves are switched. This domain swapping was observed not only with OtaC but also with glycine betaine-binding proteins from, for example, Lactococcus lactis, Bacteroides fragilis, Borrelia burgdorferi, Clostridium tetani and Pseudomonas putida [Horn et al., 2006].

The presence of multiple ABC transporters for compatible solutes is not unusual. B. subtilis contains $3 \mathrm{ABC}$ transporters for solutes that differ in substrate specificity [Horn et al., 2005]. This might also be the case for Ota and Otb of M. mazei. Unfortunately, sequence comparisons do not allow to delineate the substrate transported, mutational inactivation or biochemical experiments using the purified binding proteins are required. This is currently under way. The immunological analyses as well as the real time PCR data did not reveal a salt-dependent expression of the otb operon which could be taken as an argument against a role of Otb in osmoprotection. However, it would also be conceivable that Otb is a constitutively produced system that acts as a fast, first response system to an osmotic upshock. On the other hand, Methanosarcina strains have unusual large genomes and have acquired DNA by lateral gene transfer from bacteria [Deppenmeier et al., 2002; Galagan et al., 2002]. Some of these genes might have been acquired rather late in evolution and their products might not be integrated into the cells metabolism. This is apparently the case for some $\mathrm{F}_{1} \mathrm{~F}_{\mathrm{O}}$-like ATP synthase genes in M. acetivorans and $M$. barkeri that are not expressed under the laboratory conditions used (Lemker and Müller, unpublished). The apparent absence of an Otb homologue in the close relatives $M$. acetivorans and $M$. barkeri would support a rather late acquisition of Otb in M. mazei from bacteria. The same could have happened in $M$. burtonii.

The cellular OtaC level increased with increasing salinity, highest intracellular OtaC levels as well as transport rates were observed at $300-500 \mathrm{mM} \mathrm{NaCl}$. In addi- tion to salinity, hyperosmolarity in general induced transcription of ota genes. Furthermore, ota expression was regulated by the growth phase with an increase during stationary phase. Multiple input signals that regulate expression of solute transporters are also known from bacteria and indicate the presence of signal transduction chains that allow input of different environmental stimuli [Müller et al., 2005].

It has been reported before that the presence of glycine betaine in the growth medium downregulated the transport of glycine betaine in whole cells of M. thermophila [Proctor et al., 1997]. The same was observed here. In addition, we could demonstrate that expression of ota genes is reduced by the presence of glycine betaine in the medium. Such feed back regulation makes sense physiologically and is also observed in other, bacterial systems. From the data presented here ota expression is salt dependent and increases with the salinity of the medium. The signal transduction chain involved is unknown, but the signal apparently is not a 'salt' signal but a more general 'osmo' signal, as observed also in bacteria. However, the total amount of solutes accumulated in the absence and presence of glycine betaine in the growth medium was comparable but gene expression was reduced, indicating an additional (direct) effect of glycine betaine on ota expression. Moreover, transport rates were even more reduced indicating an additional regulatory effect of glycine betaine on the transporter itself.

\section{Experimental Procedures}

Organism, Culture Conditions and Growth Experiments M. mazei Gö1 (DSMZ 3647) was obtained from the Deutsche Sammlung von Mikroorganismen und Zellkulturen (DSMZ) and grown under strictly anaerobic conditions as described [Hippe et al., 1979]. Substrates and $\mathrm{NaCl}$ were supplemented as indicated. For growth experiments in minimal medium, the standard Methanosarcina medium (DSMZ 120) without casitone and yeast extract was used. Growth experiments were done in 16-ml Hungate tubes containing $5 \mathrm{ml}$ of medium or in 120 - $\mathrm{ml}$ serum bottles containing $50 \mathrm{ml}$ of medium. After inoculation (10\%) from an appropriate preculture, cultures were incubated at $37^{\circ} \mathrm{C}$. The optical density at $578 \mathrm{~nm}\left(\mathrm{OD}_{578}\right)$ was determined in a photometer type 1101 M (Eppendorf, Hamburg, Germany). All data points given reflect the means of duplicate tubes of one experiment, and diagrams display a representative growth curve of at least three independent replications.

\section{Preparation of Resting Cell Suspensions}

Fresh cell suspensions of M. mazei were prepared for each experiment. Cells were grown with $150 \mathrm{mM}$ methanol as the substrate in the absence or presence of glycine betaine $(1 \mathrm{~mm})$ at the given $\mathrm{NaCl}$ concentration and harvested by centrifugation 
$\left(6,000 \mathrm{~g}, 15 \mathrm{~min}, 4^{\circ} \mathrm{C}\right)$ in the exponential growth phase. The cells were washed $\left(14,000 \mathrm{~g}, 10 \mathrm{~min}, 4^{\circ} \mathrm{C}\right)$ in iso-osmotic assay buffer (0.348 g K $\mathrm{HPO}_{4}, 0.227 \mathrm{~g} \mathrm{KH}_{2} \mathrm{PO}_{4}, 0.5 \mathrm{~g} \mathrm{NH}_{4} \mathrm{Cl}, 1.2 \mathrm{~g} \mathrm{MgSO}_{4} \times$ $7 \mathrm{H}_{2} \mathrm{O}, 0.002 \mathrm{~g} \mathrm{FeSO}_{4} \times 7 \mathrm{H}_{2} \mathrm{O}, 0.4 \mathrm{~g} \mathrm{CaCl}_{2} \times 2 \mathrm{H}_{2} \mathrm{O}$ per liter), which contained $5 \mathrm{~mm}$ dithioerythritol, resazurin $(1 \mathrm{mg} / \mathrm{l})$, and $\mathrm{NaCl}$ as indicated, and resuspended in the same buffer. The resulting cell suspension containing 10-12 $\mathrm{mg}$ protein/ml was stored in a $16-\mathrm{ml}$ Hungate tube on ice until use. The protein concentration was determined as described [Schmidt et al., 1963]. All manipulations were done in an anaerobic glove box (Coy, Ann Arbor, USA) containing an atmosphere of $\mathrm{N}_{2} / \mathrm{H}_{2}(95: 5)$.

\section{Determination of Glycine Betaine Uptake}

All experiments were carried out under strictly anaerobic conditions in airtight $58-\mathrm{ml}$ bottles. After the bottles were flushed with oxygen-free nitrogen for $5 \mathrm{~min}, 5 \mathrm{ml}$ of the assay buffer with the indicated $\mathrm{NaCl}$ concentration was added. Additions of all components were made from anaerobic stock solutions with a syringe. Methanol was added to a final concentration of $25 \mathrm{mM}$ and $\left[{ }^{14} \mathrm{C}\right]$ glycine betaine (American Radiolabeled, St. Louis, Mo., USA) to a final concentration of $100 \mu \mathrm{M}(1 \mu \mathrm{Ci}$, specific activity: $55 \mu \mathrm{Ci} / \mu \mathrm{mol})$. The buffer was preincubated at $37^{\circ} \mathrm{C}$ for $5 \mathrm{~min}$. The reaction was started by addition of the cell suspension, resulting in a final protein concentration of $1 \mathrm{mg}$ protein $/ \mathrm{ml}$.

At the time points indicated, $200 \mu \mathrm{l}$ samples were withdrawn from the cell suspension by a syringe and collected by filtration through membrane filters (pore size $0.45 \mu \mathrm{m}$; Whatman). The filters were dried and dissolved in $500 \mu \mathrm{l} 3 \mathrm{M} \mathrm{NaOH}$ in a scintillation vial. $4.5 \mathrm{ml}$ of Rotiszint ecoplus (Roth, Karlsruhe, Germany) was added, the vials were vigorously shaken and radioactivity was determined in a liquid scintillation counter type $2100 \mathrm{TR}$ (Packard, Dreieich, Germany). Internal glycine betaine was calculated from the specific activity, which was determined for each experiment by measuring the radioactivity of an aliquot of the cell suspension.

\section{Generation of Antibodies}

To study the cellular level of Ota and Otb by Western blot analysis, specific antisera against one or all of the subunits was required. Since the substrate binding protein is the most conserved of three subunits it was chosen for overproduction and generation of an antiserum. For the expression studies of OtaC the gene was amplified by PCR by introducing restriction sites for BamHI or SalI at the $5^{\prime}$ or the $3^{\prime}$ end, respectively (oligonucleotides: otaCf1: CGGCCAGGATCCAACCATAATAAATTG and otaCr1: ATCAGGTAAGTCGACAGGAAGGGA). In order to overproduce $\mathrm{OtbC}$, the corresponding gene was amplified using the primers otb_forl (GGGAATGAATTCAAATTTCGC; EcoRI restriction site) and otb_rev2 (TTTTTTGTCGACGGAAGATATCAG; SalI restriction site). These restriction sites were used to clone the fragment into pMalc2stop, and transformed into E. coli $\mathrm{DH} 5 \alpha$. Cultures were grown in $\mathrm{LB}$ at $37^{\circ} \mathrm{C}$, and expression was induced at an $\mathrm{OD}_{578}$ of 0.5 by the addition of IPTG (isopropyl- $\beta$ thiogalactoside) to a final concentration of $0.3 \mathrm{~mm}$. After $2 \mathrm{~h}$ of growth, cells were harvested, washed, and disrupted in a French pressure cell. Cell debris was removed by centrifugation and the supernatant was applied to an amylose resin to purify the fusion protein. Since there is no MalE in M. mazei Göl and since a MalE antibody does not cross-react with cell-free extract of $M$. mazei Gö1 the entire fusion protein was used to immunize rabbits (Da- vids Biotechnology $\mathrm{GmbH}$, Regensburg, Germany). The antiserum against MalE-OtaC and MalE-OtbC detected only one protein in M. mazei Gö1 demonstrating its specificity (data not shown).

\section{Western Blotting}

Western blot analysis and signal detection was essentially performed as described [Lingl et al., 2003].

\section{Quantitative Real-Time PCR}

For real-time PCR analysis $M$. mazei cells were harvested in the exponential growth phase $\left(\mathrm{OD}_{578} \sim 0.8\right)$. Total RNA was prepared using the NucleoSpin ${ }^{\circledR}$ RNA II Kit (Macherey-Nagel, Düren, Germany) as described by the manufacturer. To remove residual DNA the samples were treated with RQ1 RNase-free DNase (Promega, Mannheim, Germany) according the manufacturer's protocol. cDNA synthesis was accomplished using M-MLV Reverse Transcriptase RNase H Minus, Point Mutant (Promega) according to the manufacturer's protocol. To prevent RNA degradation during this step $48 \mathrm{U}$ of 'recombinant RNasin Ribonuclease inhibitor' (Promega) were added. The qPCR reaction was run in a Rotor-Gene RG-3000 qPCR cycler (Corbett Research, Sydney, Australia) using Sybr Green as fluorescent dye. Dataanalysis was accomplished using the $2^{-\Delta \Delta C t}$-method [Livak and Schmittgen, 2001]. Real-time PCR analysis was done with 3 independent physiological parallels to ensure statistical relevance. Three open reading frames encoding a methyltransferase (MM1672), the $\beta$-subunit of the methyl-coenzyme $M$ reductase $(m c r B)$ and the $\gamma$-subunit of the methyl-coenzyme M reductase $(m c r G)$, respectively, served as internal normalizers.

\section{Quantification of Solutes}

The pool of compatible solutes of $M$. mazei was analyzed by nuclear magnetic resonance (NMR) spectroscopy. Cells of $M$. mazei were grown in $500 \mathrm{ml}$ of minimal medium with methanol as the substrate, to the exponential growth phase $\left(\mathrm{OD}_{578} \sim 0.8\right)$. The cells were harvested by centrifugation $\left(8,000 \mathrm{~g}, 15 \mathrm{~min}, 4^{\circ} \mathrm{C}\right)$ and washed in isoosmotic buffer $\left(0.348 \mathrm{~g} \mathrm{~K}_{2} \mathrm{HPO}_{4}, 0.227 \mathrm{~g}\right.$ $\mathrm{KH}_{2} \mathrm{PO}_{4}, 0.5 \mathrm{~g} \mathrm{NH}_{4} \mathrm{Cl}, 1.2 \mathrm{~g} \mathrm{MgSO}_{4} \times 7 \mathrm{H}_{2} \mathrm{O}, 0.002 \mathrm{~g} \mathrm{FeSO}_{4} \times$ $7 \mathrm{H}_{2} \mathrm{O}, 0.4 \mathrm{~g} \mathrm{CaCl}_{2} \times 2 \mathrm{H}_{2} \mathrm{O}$ per liter), which contained $5 \mathrm{mM} \mathrm{di}-$ thioerythritol, resazurin $(1 \mathrm{mg} / \mathrm{l})$, and $\mathrm{NaCl}$ as indicated. Subsequently, the cells were freeze-dried. The concentrations of intracellular solutes were measured as described previously by [Pflüger et al., 2003].

\section{Acknowledgements}

This study was supported by a grant from the Deutsche Forschungsgemeinschaft (Schwerpunktprogramm 1112). We are indebted to Ana Mingote and Helena Santos (Instituto de Tecnologia Química e Biológica, Universidade Nova de Lisboa, Oeiras, Portugal) for analyzing the pool of solutes in M. mazei. 


\section{References}

Becher B, Müller V: $\Delta \mu \mathrm{Na}^{+}$drives the synthesis of ATP via an $\Delta \mu \mathrm{Na}^{+}$-translocating $\mathrm{F}_{1} \mathrm{~F}_{0^{-}}$ ATP synthase in membrane vesicles of the archaeon Methanosarcina mazei Gö1. J Bacteriol 1994:176:2543-2550.

Brown AD: Microbial water stress. Bacteriol Rev 1976;40:803-846.

Csonka LN: Physiological and genetic responses of bacteria to osmotic stress. Microbiol Rev 1989;53:121-147.

Deppenmeier U: Redox-driven proton translocation in methanogenic archaea. Cell Mol Life Sci 2002a;59:1-21.

Deppenmeier U: The unique biochemistry of methanogenesis. Prog Nucleic Acid Res Mol Biol 2002b;71:223-283.

Deppenmeier U, et al: The genome of Methanosarcina mazei: evidence for lateral gene transfer between bacteria and archaea. J Mol Microbiol Biotechnol 2002;4:453-461.

Ferry JG: Biochemistry of methanogenesis. Crit Rev Biochem Molec Biol 1992;27:473-503.

Galagan JE, et al: The genome of Methanosarcina acetivorans reveals extensive metabolic and physiological diversity. Genome Res 2002;12:532-542.

Hippe H, Caspari D, Fiebig K, Gottschalk G: Utilization of trimethylamine and other $\mathrm{N}$ methyl compounds for growth and methane formation by Methanosarcina barkeri. Proc Natl Acad Sci USA 1979;76:494-498.

Horn C, Jenewein S, Sohn-Bosser L, Bremer E, Schmitt L: Biochemical and structural analysis of the Bacillus subtilis $\mathrm{ABC}$ transporter OpuA and its isolated subunits. J Mol Microbiol Biotechnol 2005; 10:76-91.

Horn C, Sohn-Bösser L, Breed J, Welte W, Schmitt L, Bremer E: Molecular determinants for substrate specifity of the ligandbinding protein OpuAC from Bacillus subtilis for the compatible solutes glycine betaine and proline betaine. J Mol Biol 2006;357: 592-606.

Jones WJ, Nagle DP, Whitman WB: Methanogens and diversity of archaebacteria. Microbiol Rev 1987;51:135-177.

Kempf B, Bremer E: Uptake and synthesis of compatible solutes as microbial stress responses to high-osmolality environments. Arch Microbiol 1998;170:319-330.

Lai MC, Gunsalus RP: Glycine betaine and potassium ion are the major compatible solutes in the extremely halophilic methanogen Methanohalophilus strain z7302. J Bacteriol 1992;174:7474-7477.

Lai MC, Hong TY, Gunsalus RP: Glycine betaine transport in the obligate halophilic archaeon Methanohalophilus portucalensis. J Bacteriol 2000;182:5020-5024.
Lai MC, Sowers KR, Robertson DE, Roberts MF Gunsalus RP: Distribution of compatible solutes in the halophilic methanogenic archaebacteria. J Bacteriol 1991;173:53525358.

Lingl A, Huber H, Stetter KO, Mayer F, Kellermann J, Müller V: Isolation of a complete $\mathrm{A}_{1} \mathrm{~A}_{\mathrm{O}}$ ATP synthase comprising nine subunits from the hyperthermophile Methanococcus jannaschii. Extremophiles 2003; 7: 249-257.

Livak KJ, Schmittgen TD: Analysis of relative gene expression data using real-time quantitative PCR and the $2^{-\Delta \Delta C \mathrm{t}}$ method. Methods 2001;25:402-408.

Martins LO, Huber R, Huber H, Stetter KO, DaCosta MS, Santos H: Organic solutes in hyperthermophilic Archaea. Appl Environ Microbiol 1997;63:896-902.

Mohrbach S, Krämer R: Body shaping under water stress: osmosensing and osmoregulation of solute transport in bacteria. Chem Biol Chem 2002;3:384-397.

Müller V, Spanheimer R, Santos H: Stress response by solute accumulation in archaea. Curr Opin Microbiol 2005;8:729-736.

Perski HJ, Schönheit P, Thauer RK: Sodium dependence of methane formation in methanogenic bacteria. FEBS Lett 1982;143:323326.

Pflüger K, Baumann S, Gottschalk G, Lin W, Santos H, Müller V: Lysine-2,3-aminomutase and $\beta$-lysine acetyltransferase genes of methanogenic archaea are salt induced and are essential for the biosynthesis of $\mathrm{N} \varepsilon$-acetyl- $\beta$-lysine and growth at high salinity. Appl Environ Microbiol 2003;69:60476055

Poolman B, Glaasker E: Regulation of compatible solute accumulation in bacteria. Mol Microbiol 1998;29:397-407.

Proctor LM, Lai R, Gunsalus RP: The methanogenic archaeon Methanosarcina thermophila TM-1 possesses a high-affinity glycine betaine transporter involved in osmotic adaptation. Appl Environ Microbiol 1997;63:22522257.

Roberts MF: Osmoadaptation and osmoregulation in archaea: update 2004. Front Biosci 2004;9:1999-2019.

Roberts MF, Lai MC, Gunsalus RP: Biosynthetic pathways of the osmolytes $\mathrm{N} \varepsilon$-acetyl- $\beta$-lysine, $\beta$-glutamine, and betaine in Methanohalophilus strain FDF1 suggested by nuclear magnetic resonance analyses. J Bacteriol 1992;174:6688-6693.

Robertson DE, Lai MC, Gunsalus RP, Roberts MF: Composition, variation, and dynamics of major osmotic solutes in Methanohalophilus strain FDF1. Appl Environ Microbio 1992a;58:2438-2443.
Robertson DE, Noll D, Roberts MF: Free amino acid dynamics in marine methanogens - $\beta$ amino acids as compatible solutes. J Biol Chem 1992b;267:14893-14901.

Robertson DE, Noll D, Roberts MF, Menaia JAGF, Boone DR: Detection of the osmoregulator betaine in methanogens. Appl Environ Microbiol 1990;56:563-565.

Roessler M, Müller V: Osmoadaptation in bacteria and archaea: common principles and differences. Environ Microbiol 2001;3:743754

Roessler M, Pflüger K, Flach H, Lienard T, Gottschalk G, Müller V: Identification of a saltinduced primary transporter for glycine betaine in the methanogen Methanosarcina mazei Gö1. Appl Environ Microbiol 2002;68: 2133-2139.

Schiefner A, Breed J, Bosser L, Kneip S, Gade J, Holtmann G, Diederichs K, Welte W, Bremer E: Cation-pi interactions as determinants for binding of the compatible solutes glycine betaine and proline betaine by the periplasmic ligand-binding protein ProX from Escherichia coli. J Biol Chem 2004a;279:55885596.

Schiefner A, Holtmann G, Diederichs K, Welte W, Bremer E: Structural basis for the binding of compatible solutes by ProX from the hyperthermophilic archaeon Archaeoglobus fulgidus. J Biol Chem 2004b;279:4827048281

Schmidt K, Liaanen-Jensen S, Schlegel HG: Die Carotinoide der Thiorodaceae. Arch Mikrobiol 1963;46:117-126.

Sleator RD, Hill C: Bacterial osmoadaptation: the role of osmolytes in bacterial stress and virulence. FEMS Microbiol Rev 2001;26:4971.

Sowers KR, Gunsalus RP: Halotolerance in Methanosarcina spp.: role of $\mathrm{N}^{\varepsilon}$-acetyl- $\beta$-lysine, $\alpha$-glutamate, glycine betaine, and $\mathrm{K}^{+}$as compatible solutes for osmotic adaptation. Appl Environ Microbiol 1995;61:43824388.

Sowers KR, Robertson DE, Noll D, Gunsalus RP, Roberts MF: $\mathrm{N}^{\varepsilon}$-acetyl- $\beta$-lysine: an osmolyte synthesized by methanogenic archaebacteria. Proc Natl Acad Sci USA 1990;87: 9083-9087.

Thauer RK: Biochemistry of methanogenesis: a tribute to Marjory Stephenson. Microbiology $1998 ; 144: 2377-2406$.

Wood JM: Osmosensing by bacteria: signals and membrane-based sensors. Microbiol Mol Biol Rev 1999;63:230-262.

Wood JM, Bremer E, Csonka LN, Krämer R, Poolman B, van der Heide T, Smith LT: Osmosensing and osmoregulatory compatible solute accumulation by bacteria. Comp Biochem Physiol [A] 2001;130:437-460. 